\title{
Fertilizer management for improving yield and quality of off-season tomatoes in high tunnel
}

\author{
Parvez Khan ${ }^{1 *}$, Muhammad Imtiaz ${ }^{1}$ and Shahzada Asif Ali $^{1}$ \\ 1. Nuclear Institute for Food and Agriculture (NIFA), Tarnab, Peshawar, Khyber Pakhtunkhwa, Pakistan \\ *Corresponding author's email: parvez_08@yahoo.com \\ Citation \\ Parvez Khan, Muhammad Imtiaz and Shahzada Asif Ali. Fertilizer management for improving yield and quality of \\ off-season tomatoes in high tunnel. Pure and Applied Biology. Vol. 10, Issue 4, pp1466-1476. \\ http://dx.doi.org/10.19045/bspab.2021.100152
}

Received: 12/01/2021 Revised: 26/03/202

Accepted: 06/04/2021

Online First: 22/04/2021

\section{Abstract}

Tomato is well known for its quality and nutritional value all over the world but untimely and imbalanced fertilizer application has a severe effect on yield \& quality of tomato. To investigate the effect of specific timing of fertilizer application for off-season tomato (Sahel hybrid), a study was conducted at Nuclear Institute for Food and Agriculture (NIFA), Peshawar. Nitrogen, phosphorus and potassium (NPK) fertilizers were applied at the rate of 10-10-15 $\mathrm{kg} \mathrm{ha}^{-1}$ at 7, 14 and 21 days intervals, starting after establishment of crop (30 days after transplanting) till mid of June. The current study was carried out under randomized complete block (RCB) design having three replicates of four treatments. The maximum fruit yield (2.94 t/ 10 Marla tunnel) was recorded in the treatment receiving NPK @ 10-10-15 $\mathrm{kg} \mathrm{ha}^{-1}$ at 7 days interval that was significantly $(\mathrm{P} \leq 0.05)$ higher as compared to those fertilized at 14 days $(1.75 \mathrm{t} / 10$ Marla tunnel $)$ and 21 days (0.83 t/ 10 Marla tunnel) intervals, while minimum (0.5 t/ 10 Marlas) was recorded in control. Maximum grade-A tomatoes having above $100 \mathrm{~g}$ weight per fruit $(62 \%)$, density $\left(1.30 \mathrm{~g} / \mathrm{cm}^{3}\right)$, chlorophyll content / SPAD value (57.63), total acidity $(0.44 \%)$, protein content $(15.4 \%)$, total soluble solids $\left(5.4{ }^{\circ}\right.$ Brix $), \mathrm{N}(1.25 \%), \mathrm{P}(0.20 \%), \mathrm{K}(1.45 \%)$ in fruit and improved shelf-life $(9$ days) were recorded with the NPK application at 7 days intervals. The concentration of vitamin C showed increasing trend along with decrease in $\mathrm{N}$ dose at all application times. This study suggested that application of timely and balanced fertilizer may be a good strategy to get higher and good quality yield of off-seasonally grown tomatoes in the tunnels.

Keywords: Chemical composition; Concentration; Mineral content; Nutrients; Sahel; Time interval

\section{Introduction}

Tomato (Lycopersicum esculentum), widely used as a salad as well as in cooking all over the world, is an important vegetable. It is a nutritious vegetable having high contents of $\mathrm{Na}, \mathrm{K}$, iron, vitamins $\mathrm{A} \& \mathrm{C}$ and many antioxidants like lycopene [1]. During 2016, the tomato was cultivated on about an area of
4.85 million hectares, from which around 176.85 million tonnes production was achieved. Pakistan is the $35^{\text {th }}$ largest country in the world with respect to tomato production [2]. During 2016-17, total tomato production in Pakistan was recorded 601.098 thousand tones from the cultivated area of 63.2 thousand hectares [3]. The largest 
tomato producer province was Baluchistan followed by Sindh, KP and Punjab [4].

Contrary to the recent past, nutrition is being considered as an integral part of food security [5]. Accordingly, all four dimensions of food security, viz. the accessibility, availability, stability and utilization of macro and micronutrients are deemed components of food security [6]. Subsequent to this, a focus on the role of small producers in the agriculture sector is an important element. Production of off-season vegetables under high tunnels is an expanding opportunity to enhance food production of the country. High tunnel farming techniques are used to produce off-season vegetables such as tomatoes, cucumbers, chilies, sweet peppers, egg plants and gourds. Similarly, high tunnels have a wide range of advantages like yield and quality enhancement, avoiding the adverse environmental conditions, early crop production aiming at achieving high market value, etc. [7]. Tomato, one of the vital and widely cultivated high tunnel vegetables, possesses a wide range of vital compounds including solid \& insoluble solids (5-7\%), water (about 90\%), carotenoids, citric acid, phenols, flavonoids, vitamins and minerals [8]. It also contains remarkable amounts of lycopene, antioxidants and carotene that play an important role in preventing cancer of many types [9]. However, the ultimate goal is to enhance quality production of tomatoes in high tunnels while improving fertilizer use efficiency and enhancing the socio-economic status of subsistence-level growers and small land-holders.

Nutrient management plays a significant role in enhancing production whether it is applied in open fields or while growing off-season vegetables. Nitrogen, phosphorus and potassium application in the form of organic and inorganic sources at critical growth stages (flowering, fruit setting and fruit development) of the tomato has been reported to enhance their growth and development. For example, $\mathrm{N}$ requirement of tomatoes is moderate during foliage growth, until fruit development. $\mathrm{P}$ is very important for vigorous growth and fruit production. Likewise, $\mathrm{K}$ is needed for fruit development and enlargement [10]. However, USDA (United States Department of Agriculture) together with the Fertilizer Institute promotes a specific framework called $4 \mathrm{R}$ nutrient stewardship (4Rs) that aims at increasing productivity and profitability for growers in both highly intensive agricultural systems and subsistence-level growers. The first 2Rs (right source and right rate) are commonly followed during crop production in Pakistan. However, the other 2Rs (right time and right place) are reported to be rarely practiced by farming communities, which results in low nutrient use efficiency and low economic returns $[3,5]$. The core objectives of the current study were to assess the suitable time interval (right time) for NPK application on yield and quality parameters of $F_{1}$ hybrid "Sahel" tomatoes grown in high tunnel.

\section{Materials and Methods}

The study was planned in a high tunnel measuring $28 \mathrm{ft}$. $\times 120 \mathrm{ft}$. with $11 \mathrm{ft}$. high bend fitted with a polyethylene plastic and 6 ft. roll-up sides at Nuclear Institute for Food and Agriculture (NIFA), Peshawar. The experiment was laid out in randomized complete block (RCB) design having three replicates of four treatments. The treatments consisted of different time intervals for the application of NPK to the tomato crop. A nursery of the $F_{1}$ hybrid tomato cultivar "Sahel" was raised in plastic tubes $(6 \mathrm{~cm} \times 4$ $\mathrm{cm})$. After thirty days of germination, the nursery was transferred to tunnel. The soil of experimental tunnel was silt loam, alkaline in nature and non-saline. The soil was marginal in terms of the contents of organic matter $(\mathrm{OM}), \mathrm{P}, \mathrm{K}$ and adequate with respect to potassium $\left(\mathrm{K}_{2} \mathrm{O}\right)$ (Table 1). The spacing between plants and rows were maintained at $1.5 \mathrm{ft}$. and $3.0 \mathrm{ft}$. respectively. After thirty 
days of germination, the nursery was transferred into the tunnel. Upon establishment of crop about one month after transplanting, NPK @ 10-10-15 kg/ha was applied at 7 days intervals ( $\mathrm{T}_{1}$ : high dose), 14 days intervals ( $\mathrm{T}_{2}$ : medium dose) and 21 days intervals $\left(\mathrm{T}_{3}\right.$ : low dose) during the whole season. All the three doses were compared with control $\left(\mathrm{T}_{0}\right.$ : no fertilizer). The experiment was properly maintained following standard cultural practices as commonly observed in high tunnel farming. Tomato fruit yield in each treatment was collected at each harvest and weighed in kilograms $(\mathrm{kg})$. The total yield per treatment was calculated by adding the yields at all harvests for the same treatment.

Fruit and straw samples were washed initially with tap water and then with distilled water. After washing, these samples were firstly airdried and then oven-dried at $70{ }^{\circ} \mathrm{C}$ till constant weight. All these samples were then subjected to grinding in a stainless steel grinder. Soil samples collected at depths of 0$15 \mathrm{~cm}$ and $15-30 \mathrm{~cm}$ from different places in the tunnel were mixed to make composite samples. Stones and plant residues were removed from these samples and then the samples were dried in the laboratory. The soil samples were then grinded and sieved through $2 \mathrm{~mm}$ sieve. After labeling, the soil samples were stored in plastic containers. These soil samples were analyzed in the laboratory for determination of $\mathrm{N}, \mathrm{P}, \mathrm{K}$ and soil organic carbon. Particle size analysis was done using hydrometer method [11]. Soil nitrogen was determined by using Kjeldahl apparatus [12]. Soil phosphorus was assessed using spectrophotometer at $880 \mathrm{~nm}$ [13]. Soil potassium was determined by using flame photometer. Organic carbon content in the soil was determined through dichromate approach, using combustion at $160{ }^{\circ} \mathrm{C}$ for 30 minutes [14].

Nitrogen in plant samples was determined using Kjeldahl apparatus, according to
Gunning and Hibbard's method [12]. Total phosphorus in plant was determined by analyzing the samples through spectrometer at $400 \mathrm{~nm}$ [13] while potassium in plant samples was assessed by using flame photometer [13]. The protein and moisture contents of the tomato fruits were determined by standard protocols [15]. Potassium concentrations of tomato fruits were assessed by flame photometer, $\mathrm{P}$ by UV-visible spectrophotometer and $\mathrm{N}$ by Kjeldahl apparatus [16]. Protein was assessed by the Folin phenol reagent method by [17]. Vitamin C contents was determined according to 2,6-dichlorophenolindophenol method by [18].

The data collected were arranged and subjected to analysis using Statistix 8.1. Data were recorded as mean of three replications and the means of various treatments were compared using LSD (Least Significance Difference) test.

\section{Results and Discussion \\ Soil physico-chemical properties}

The soil samples were collected before crop transplanting from two depths i.e. $0-15 \mathrm{~cm} \&$ $15-30 \mathrm{~cm}$. Samples of same depth were mixed to form their composite samples and then were analyzed for soil physical \& chemical parameters (Table 1). Results showed that the soil in experimental tunnel was silt loam and deficient in nitrogen, phosphorus and organic carbon. The organic matter $(0.88 \%)$ in the upper depth $(0-15 \mathrm{~cm})$ was higher than the lower depth i.e. $15-30 \mathrm{~cm}$ $(0.41 \%)$. The amount of organic $\mathrm{C}$ in upper depth $(0-15 \mathrm{~cm})$ was $0.52 \%$ which was found $0.24 \%$ in the lower depth $(15-30 \mathrm{~cm})$. Total nitrogen content in upper depth was found $0.05 \%$ as compared to $0.03 \%$ in the lower depth. Available phosphorus in the $0-15 \mathrm{~cm}$ depth was $7.5 \mu \mathrm{g} \mathrm{P} / \mathrm{g}$ soil and decreased to $5.9 \mu \mathrm{g} \mathrm{P} / \mathrm{g}$ soil in $15-30 \mathrm{~cm}$ depth. Maximum $\mathrm{K}(80 \mu \mathrm{g} / \mathrm{g})$ was recorded in upper portion ( 0 $15 \mathrm{~cm})$ while minimum $\mathrm{K}(60 \mu \mathrm{g} / \mathrm{g})$ was found in the lower portion $(15-30 \mathrm{~cm})$. Soil 
was alkaline in reaction $(\mathrm{pH} 7.9-8.0)$, nonsaline (EC $0.24-0.25 \mathrm{dS} / \mathrm{m}$ ), moderately calcareous in nature 15.0 to $14.5 \%$ lime.

Table 1. Soil physico-chemical properties before transplantation

\begin{tabular}{|c|c|c|c|}
\hline \multirow{2}{*}{ Physico-chemical properties } & \multicolumn{2}{|c|}{ Soil depth } & \multirow{2}{*}{ Mean } \\
\cline { 2 - 4 } & $\mathbf{0 - 1 5} \mathbf{~ c m}$ & $\mathbf{1 5 - 3 0} \mathbf{~ c m}$ & 7.95 \\
\hline $\mathrm{pH}$ & 7.9 & 8.0 & 0.25 \\
\hline Electrical conductivity $(\mathrm{dS} / \mathrm{m})$ & 0.24 & 0.25 & 0.38 \\
\hline Organic carbon $(\%)$ & 0.52 & 0.24 & 0.65 \\
\hline Organic matter $(\%)$ & 0.88 & 0.41 & 0.04 \\
\hline Nitrogen $(\%)$ & 0.05 & 0.03 & 6.7 \\
\hline Phosphorus $(\mu \mathrm{g} / \mathrm{g})$ & 7.5 & 5.9 & 70 \\
\hline Potassium $(\mu \mathrm{g} / \mathrm{g})$ & 80 & 60 & 14.75 \\
\hline Lime content $(\%)$ & 15.0 & 14.5 & \\
\hline Soil texture & & Silt loam & \\
\hline
\end{tabular}

\section{Tomato fruit yield}

Mature tomato fruits in each treatment were collected at each harvest and weighed in kilograms. The total yield per treatment was calculated by adding the yield at all harvests for the same treatment. The effect of NPK on fresh yield of tomato applied at different days' intervals is presented in (Table 2). The application of NPK at 7 days interval $\left(T_{1}\right)$ produced maximum yield $(294 \mathrm{~kg} /$ Marla) followed by $175 \mathrm{~kg} /$ Marla (14 days interval i.e. $\left.\mathrm{T}_{2}\right)$ and $83 \mathrm{~kg} / \mathrm{Marla}$ (21 days interval i.e. $\mathrm{T}_{3}$ ). It was also observed that NPK applied at 7,14 and 21 days intervals enhanced the yield significantly $(\mathrm{P} \leq 0.05)$ as compared to $\mathrm{T}_{0}$ i.e. no-NPK (50 kg/Marla). The highest dry straw yield $\left(35 \mathrm{~kg} /\right.$ Marla) was recorded in $\mathrm{T}_{1}$ followed by $\mathrm{T}_{2} \quad(25 \mathrm{~kg} /$ Marla $), \mathrm{T}_{3}(18$ $\mathrm{kg} / \mathrm{Marla})$ and lowest in control (10 $\mathrm{kg} / \mathrm{Marla})$. The results further indicated that there was a significant $(\mathrm{P}<0.05)$ difference among the treatments due to NPK application at different intervals. The results of our study were similar to [19], who investigated and reported that the response of various tomato cultivars varied to different rates of nitrogen and phosphorus application. In his study, NP fertilizers were applied at three different rates. He found that significantly higher fruit yield was obtained at NP application @ 110 $\mathrm{kg} \mathrm{N}+120 \mathrm{~kg} \mathrm{P}_{2} \mathrm{O}_{5} / \mathrm{ha}$. The results of our findings were also supported by [20] who reported that high NPK concentrations produce higher tomato fruit weight as compared to control. Moreover, increasing the phosphorus concentration gave maximum yield per tomato plant. Results were also in lines with [21], who reported that application of NPK in lower amounts may result in poor plant growth and less fruit production. From the present findings it was suggested that NPK fertilizer should be applied at 14 days interval to obtain economically higher yield. 
Table 2. Effect of time intervals of NPK application on fruit and straw yield of off-season tomato

\begin{tabular}{|c|c|c|}
\hline \multirow{2}{*}{ Treatments } & Tomato yield & Dry straw yield \\
\cline { 2 - 3 } & kg/Marla & kg /Marla \\
\hline $\mathrm{T}_{0}($ Control $)$ & $50 \mathrm{~d}$ & $10 \mathrm{~d}$ \\
\hline $\mathrm{T}_{1}(7$ days interval $)$ & $294 \mathrm{a}$ & $35 \mathrm{a}$ \\
\hline $\mathrm{T}_{2}(14$ days interval $)$ & $175 \mathrm{~b}$ & $25 \mathrm{~b}$ \\
\hline $\mathrm{T}_{3}(21$ days interval $)$ & $83 \mathrm{c}$ & $18 \mathrm{c}$ \\
\hline
\end{tabular}

Values in each column indicated by similar letters are not significantly different at $\mathrm{P} \leq 0.05$

\section{Tomato fruit size/grading}

The data regarding the effect of NPK applied after each 7,14 and 21 days intervals on fruit size (Grading) is presented in (Table 3). The maximum $\%$ age of A-Grade (100-140 $\mathrm{g} /$ fruit) was recorded in $\mathrm{T}_{1}(62 \%)$ by application of NPK after each 7 days interval followed by $\mathrm{T}_{2}(48 \%)$ and $\mathrm{T}_{3}(36 \%)$ after each 14 and 21 days intervals, respectively. This increase in weight may be attributed to more nutrients availability and increased water and nutrients uptake by the plant that ultimately may result in higher photosynthesis rate and in return more food accumulation in fruits. The lowest (25\%) AGrade was found in control $\left(\mathrm{T}_{0}\right)$. It was examined the performance of eight tomato hybrids under plastic tunnel for early growth and various agronomic parameters [22]. He reported that the average single fruit weight of various tomato cultivars ranged between 103-202 $\mathrm{g}$ which is in line with our findings. Similar finding was obtained by $[23,24]$ who reported that under plastic tunnel the no. of fruits/ plant, single fruit weight and total weight of fruits/ plant were in the ranges of $20-57, \quad 53-167 \quad \mathrm{~g}$ and $2.0-4.78 \mathrm{~kg}$, respectively. Likewise, [25] evaluated tuff and sand soil-less substrates in comparison with conventional growing in soil for the growth of tomato in a non-circulating open culture. Tomato plant grown in soil or tuff gave higher weight of fruit which ranged between 120-163 g whereas substrate has no effect on weight of fruit, which was quite similar to our findings. Moreover, foliar fertilization significantly increased the tomato growth, yield as well as quality [26]. The average fruit weight $(81.60 \mathrm{~g})$ was high with foliar spray along with NPK application.

Table 3. Effect of time intervals of NPK application on fruit grading of off-season tomato

\begin{tabular}{|c|c|c|c|}
\hline \multirow{2}{*}{ Treatments } & \multicolumn{3}{|c|}{ Tomato Grading (\%) } \\
\cline { 2 - 4 } & $\begin{array}{c}\text { Grade-A } \\
(\mathbf{1 0 0 - 1 4 0} \mathbf{g} / \text { fruit })\end{array}$ & $\begin{array}{c}\text { Grade-B } \\
\mathbf{5 0 - 1 0 0} \mathbf{g} / \mathbf{f r u i t})\end{array}$ & $\begin{array}{c}\text { Grade-C } \\
(\mathbf{2 5 - 5 0} \text { g/fruit })\end{array}$ \\
\hline $\mathrm{T}_{0}$ (Control) & $25 \mathrm{c}$ & $33 \mathrm{~b}$ & $42 \mathrm{a}$ \\
\hline $\mathrm{T}_{1}(7$ days interval $)$ & $62 \mathrm{a}$ & $28 \mathrm{c}$ & $10 \mathrm{c}$ \\
\hline $\mathrm{T}_{2}(14$ days interval $)$ & $48 \mathrm{~b}$ & $39 \mathrm{a}$ & $13 \mathrm{~b}$ \\
\hline $\mathrm{T}_{3}(21$ days interval $)$ & $36 \mathrm{~b}$ & $42 \mathrm{a}$ & $22 \mathrm{~b}$ \\
\hline
\end{tabular}

Values in each column indicated by similar letters are not significantly different at $\mathrm{P} \leq 0.05$ 
Density, moisture, chlorophyll content and shelf life of tomato

The effect of NPK applied at different days' intervals under high tunnel on tomato fruit density, moisture \%age, leaves chlorophyll content (SPAD value) and shelf life of tomato fruit is summarized in Table 4. The highest density $\left(1.30 \mathrm{~g} / \mathrm{cm}^{3}\right)$ among the treatments was observed for $T_{1}$ followed by $T_{2}(1.20$ $\left.\mathrm{g} / \mathrm{cm}^{3}\right)$ and $\mathrm{T}_{3}\left(0.99 \mathrm{~g} / \mathrm{cm}^{3}\right)$ whereas control $\left(\mathrm{T}_{0}\right)$ exhibited lowest density $\left(0.80 \mathrm{~g} / \mathrm{cm}^{3}\right)$. These results are in range with the values reported by [27]. They found 0.95 to 1.96 $\mathrm{g} / \mathrm{cm}^{3}$ density in various open pollinated and hybrid tomato cultivars. Similarly, maximum moisture $\left(93.7 \%\right.$ ) content was recorded for $\mathrm{T}_{2}$ having 14 days intervals of NPK application followed by $\mathrm{T}_{1}(92.65 \%)$ having 7days interval and control $(90.80 \%)$, while $\mathrm{T}_{3}$ showed minimum moisture content (90.40\%). It was reported that $83.40-93.20 \%$ moisture content of tomato cultivars which justify our findings [27]. In case of chlorophyll content, the highest SPAD value (57.63) was noted for $T_{1}$ having each 7 days interval of NPK application followed by $\mathrm{T}_{2}$ (56.43) and $\mathrm{T}_{3}$ (53.54). However, $\mathrm{T}_{0}$ has lowest chlorophyll content (46.28) among all the treatments. It was reported that 61.2 SPAD value of chlorophyll content after 84 days of nursery transplantation which are almost similar to our findings [28]. Potassium is one of the major factors influencing the tomato shelf life [29]. The results reveal that both treatments $T_{1}$ and $T_{2}$ have maximum shelf life ( 9 days) followed by $\mathrm{T}_{3}$ (8 days) and $\mathrm{T}_{0}$ (7 days). This may be attributed to the application of potassium, which was not applied to the control treatment $\left(\mathrm{T}_{0}\right)$. The findings were also supported by [30,31]; they reported that $375-400 \mathrm{~kg} \mathrm{~K}_{2} \mathrm{O} / \mathrm{ha}$ increased the post-harvest life of tomato fruits. The effect of enhanced potassium levels on the shelf life of tomato was also reported by [32]. Potassium occupies a pivotal position in improving many of the post-harvest quality traits in fruits of tomato as well as other vegetables [33]. Plants receiving higher $\mathrm{K}$ applications mature earlier and show minimum post-harvest losses like weight loss, thus help in retaining fruit texture and structure as was investigated by $[31,34]$ who also reported that application of potassium @ $375-400 \mathrm{~kg} \mathrm{~K}_{2} \mathrm{O} / \mathrm{ha}$ increased the postharvest life of tomato fruits.

Table 4. Effect of time intervals of NPK application on density, moisture, chlorophyll content and shelf life of off-season tomato

\begin{tabular}{|c|c|c|c|c|}
\hline Treatments & Density $\left(\mathbf{g} / \mathbf{c m}^{\mathbf{3}}\right)$ & Moisture (\%) & $\begin{array}{c}\text { Chlorophyll content } \\
\text { (SPAD value) }\end{array}$ & $\begin{array}{c}\text { Shelf life } \\
\text { (Days) }\end{array}$ \\
\hline $\mathrm{T}_{0}($ Control $)$ & $0.80 \mathrm{~b}$ & $90.80 \mathrm{a}$ & $46.28 \mathrm{~b}$ & $7.0 \mathrm{~b}$ \\
\hline $\mathrm{T}_{1}(7$ days interval) & $1.30 \mathrm{a}$ & $92.65 \mathrm{a}$ & $57.63 \mathrm{a}$ & $9.0 \mathrm{a}$ \\
\hline $\mathrm{T}_{2}(14$ days interval) & $1.20 \mathrm{a}$ & $93.70 \mathrm{a}$ & $56.43 \mathrm{a}$ & $9.0 \mathrm{a}$ \\
\hline $\mathrm{T}_{3}(21$ days interval) & $0.99 \mathrm{a}$ & $90.40 \mathrm{a}$ & $53.54 \mathrm{a}$ & $8.0 \mathrm{ab}$ \\
\hline
\end{tabular}

Values in each column indicated by similar letters are not significantly different at $\mathrm{P} \leq 0.05$

\section{NPK contents in tomato fruit}

Effect of NPK fertilizer applied with different days' intervals on the NPK content in fruit of tomato is described in (Table 5). Maximum $\mathrm{N}$ content in tomato fruit was recorded in $\mathrm{T}_{1}(2.43 \%)$ followed by $\mathrm{T}_{2}$ $(2.33 \%), \mathrm{T}_{3}(2.16 \%)$ and $\mathrm{T}_{0}(1.32 \%)$. Likewise, maximum $\mathrm{P}$ content was observed in $\mathrm{T}_{1}(0.44 \%)$ followed by $\mathrm{T}_{2}(0.39 \%), \mathrm{T}_{3}$ $(0.30 \%)$ and $\mathrm{T}_{0}(0.18 \%)$. In case of $\mathrm{K}$, the 
highest $\mathrm{K}$ content was recorded in $\mathrm{T}_{1}(3.45 \%)$ followed by $\mathrm{T}_{2}(3.36 \%), \mathrm{T}_{3}(2.80 \%)$ and $\mathrm{T}_{0}$ $(2.42 \%)$. It was reported that the application of NPK fertilizer tremendously increased $\mathrm{N}$
$(2-3.62 \%), \quad \mathrm{P}(0.23-0.47 \%)$ and $\mathrm{K}(3.2-$ $7.88 \%$ ) contents of tomato fruit which justify our results [35].

Table 5. Effect of time intervals of NPK application on the mineral contents in off-season tomato fruit

\begin{tabular}{|c|c|c|c|}
\hline Treatments & $\mathbf{N}(\boldsymbol{\%})$ & $\mathbf{P}(\boldsymbol{\%})$ & $\mathbf{K}(\boldsymbol{\%})$ \\
\hline $\mathrm{T}_{0}$ (Control) & $1.32 \mathrm{c}$ & $0.18 \mathrm{c}$ & $2.42 \mathrm{c}$ \\
\hline $\mathrm{T}_{1}(7$ days interval $)$ & $2.43 \mathrm{a}$ & $0.44 \mathrm{a}$ & $3.45 \mathrm{a}$ \\
\hline $\mathrm{T}_{2}(14$ days interval $)$ & $2.33 \mathrm{ab}$ & $0.39 \mathrm{a}$ & $3.36 \mathrm{a}$ \\
\hline $\mathrm{T}_{3}(21$ days interval $)$ & $2.16 \mathrm{~b}$ & $0.30 \mathrm{~b}$ & $2.80 \mathrm{~b}$ \\
\hline
\end{tabular}

Values in each column indicated by similar letters are not significantly different at $\mathrm{P} \leq 0.05$

\section{NPK contents in tomato straw}

Effect of NPK fertilizer applied with different days' intervals on the NPK contents in straw of tomatoes is described in (Table 6). Maximum $\mathrm{N}$ was recorded in $\mathrm{T}_{1}(1.25 \%)$ followed by $\mathrm{T}_{2}(1.19 \%), \mathrm{T}_{3}(1.05 \%)$ and $\mathrm{T}_{0}$ $(0.80 \%)$. Similarly, the highest $\mathrm{P}$ content was found in $\mathrm{T}_{1}(0.20 \%)$ followed by $\mathrm{T}_{2}(0.18 \%)$, $\mathrm{T}_{3}(0.17 \%)$ and $\mathrm{T}_{0}(0.10 \%)$. In case of $\mathrm{K}$, the highest $\mathrm{K}$ content was observed in $\mathrm{T}_{1}(1.45 \%)$ as compared to $\mathrm{T}_{2}(1.35 \%), \mathrm{T}_{3}(1.23 \%)$ and $\mathrm{T}_{0}$ $(1.08 \%)$. The results of the finding revealed overall uptake of NPK by straw was higher when NPK fertilizer was applied at 7 days intervals as compared to other treatments. It was reported that nitrogen, phosphorus and potassium are required for better plant growth and fruit development, so their lower amounts decreased the yield of tomato plant [21].

Table 6. Effect of time intervals of NPK application on the mineral contents in off-season tomato straw

\begin{tabular}{|c|c|c|c|}
\hline Treatments & $\mathbf{N}(\boldsymbol{\%})$ & $\mathbf{P}(\boldsymbol{\%})$ & $\mathbf{K}(\boldsymbol{\%})$ \\
\hline $\mathrm{T}_{0}$ (Control) & $0.80 \mathrm{c}$ & $0.10 \mathrm{~b}$ & $1.08 \mathrm{c}$ \\
\hline $\mathrm{T}_{1}(7$ days interval) & $1.25 \mathrm{a}$ & $0.20 \mathrm{a}$ & $1.45 \mathrm{a}$ \\
\hline $\mathrm{T}_{2}(14$ days interval $)$ & $1.19 \mathrm{ab}$ & $0.18 \mathrm{a}$ & $1.35 \mathrm{ab}$ \\
\hline $\mathrm{T}_{3}(21$ days interval $)$ & $1.05 \mathrm{~b}$ & $0.17 \mathrm{a}$ & $1.23 \mathrm{~b}$ \\
\hline
\end{tabular}

Values in each column indicated by similar letters are not significantly different at $\mathrm{P}<0.05$

\section{Total NPK uptake of tomato}

Plant nutrition is one of the vital factors affecting the proper growth \& development of the plants. Methods as well as time of fertilizer application are key components for supplying the nutrients to the plants adequately as the soil applied fertilizers may be lost or fixed resulting in lower efficacy of these nutrients. The data in Table 7 shows the effect of NPK applied after each 7, 14 and 21 days intervals on total NPK uptake of tomato. The maximum total nitrogen uptake $(9.62 \mathrm{~kg} /$ 10 Marla tunnel) was recorded in $T_{1}$ fertilized at 7 days interval followed by $T_{2}(5.51 \mathrm{~kg} / 10$ 
Marla tunnel) and the minmum was recorded in $\mathrm{T}_{0}(0.14 \mathrm{~kg} / 10$ Marla tunnel). Likewse highest total phosphorus uptake $(1.64 \mathrm{~kg} / 10$ Marla tunnel) was recorded in $\mathrm{T}_{1}$ followed by $\mathrm{T}_{2}(0.92 \mathrm{~kg} / 10$ Marla tunnel $), \mathrm{T}_{3}(0.54 \mathrm{~kg} / 10$ Marla tunnel $)$ and $\mathrm{T}_{0}(0.02 \mathrm{~kg} / 10$ Marla tunnel). In case of $\mathrm{K}$, the highest $\mathrm{K}$ uptake was recorded in $\mathrm{T}_{1}(12.44 \mathrm{~kg} / 10$ Marla tunnel) as compared to $\mathrm{T}_{2}(7.05 \mathrm{~kg} / 10 \mathrm{Marla}$ tunnel), $\mathrm{T}_{3}\left(4.41 \mathrm{~kg} / 10\right.$ Marla tunnel) and $\mathrm{T}_{0}$ $(0.22 \mathrm{~kg} / 10$ Marla tunnel). It was investigated that NPK nutrients are required for better plant growth and fruit development, so their lower concentrations decreased NPK uptake and ultimately the plant yield [21].

Table 7. Effect of time intervals of NPK application on total NPK uptake of off-season tomato

\begin{tabular}{|c|c|c|c|}
\hline \multirow{2}{*}{ Treatments } & $\mathbf{N}$ & $\mathbf{P}$ & K \\
\cline { 2 - 4 } & \multicolumn{3}{|c|}{ kg/ 10 Marla tunnel } \\
\hline $\mathrm{T}_{0}$ (Control) & $0.14 \mathrm{~d}$ & $0.02 \mathrm{~d}$ & $0.22 \mathrm{~d}$ \\
\hline $\mathrm{T}_{1}(7$ days interval) & $9.62 \mathrm{a}$ & $1.64 \mathrm{a}$ & $12.44 \mathrm{a}$ \\
\hline $\mathrm{T}_{2}(14$ days interval) & $5.51 \mathrm{~b}$ & $0.92 \mathrm{~b}$ & $7.05 \mathrm{~b}$ \\
\hline $\mathrm{T}_{3}(21$ days interval $)$ & $3.60 \mathrm{c}$ & $0.54 \mathrm{c}$ & $4.41 \mathrm{c}$ \\
\hline
\end{tabular}

Values in each column indicated by similar letters are not significantly different at $\mathrm{P} \leq 0.05$

\section{Nutritional quality of tomato fruit}

TSS (total soluble solids), $\mathrm{pH}$, total acidity, protein \& vitamin $\mathrm{C}$ content are key quality parameters contributing towards the stability of tomatoes while processing and storage. The effect of NPK fertilizer applied with different days' intervals on the nutritional quality of tomatoes is described in Table 8. As depicted from the table, the total soluble solid (TSS) content varied from $5.4{ }^{\circ}$ Brix in $\mathrm{T}_{1}$ receiving fertilizer application at 7 days intervals of time to $4.6^{\circ} \mathrm{Brix}$ in $\mathrm{T}_{0}$ receiving no fertilizer at all. [36] noted that maximum TSS contents was achieved in cultivar Sahel (6.33 ${ }^{\circ}$ Brix). This may be justified on account of higher potassium application as was reported by [34] that higher application of $\mathrm{K}$ resulted in significantly higher concentration of total soluble solids. $\mathrm{pH}$ of tomatoes juice (Table 8) was highest in treatment receiving fertilizer application at 14 days intervals (4.6) while the least (3.9) was found in treatment receiving fertilizer application at 7 days intervals. Non-significance difference was found in all treatments regarding total acidity content, however, the highest value was recorded for $\mathrm{T}_{1}(0.44 \%)$ and the lowest value for $\mathrm{T}_{0}(0.34 \%)$.

Highest protein content $(15.40 \%)$ was found in tomato fruits receiving fertilizer application at 7 days intervals whereas the lowest one $(8.75 \%)$ was recorded in the tomato fruits that were applied no fertilizer at all. Vitamin $\mathrm{C}$ content of tomato juice ranged from 17.06 to $29.64 \mathrm{mg} 100 \mathrm{~g}^{-1}$, with the highest content in treatment of 21 days intervals of fertilizer application and the least content in that of no fertilizer application. Generally, tomatoes are not a good source of protein, but hybrid cultivars containing protein up to $12 \%$ have been reported by [37]. The higher content of protein in the tomato fruits, in the present study, was due to the consistent supply of nitrogen which is a key component for protein biosynthesis. Our results regarding higher protein content may be fairly supported by the ' $\mathrm{C} / \mathrm{N}$ balance theory' which explains that with consistent availability of $\mathrm{N}$, plants will go on making high $\mathrm{N}$ compounds like protein. 
Table 8. Effect of time intervals of NPK application on the nutritional quality of off-season tomato fruit

\begin{tabular}{|c|c|c|c|c|c|}
\hline Treatments & $\begin{array}{c}\text { TSS } \\
\left({ }^{\mathbf{B}} \mathbf{B r i x}\right)\end{array}$ & $\mathbf{p H}$ & $\begin{array}{c}\text { Total } \\
\text { Acidity }(\%)\end{array}$ & Protein (\%) & Vitamin C (mg /100g) \\
\hline $\mathrm{T}_{0}$ (Control) & $4.6 \mathrm{~b}$ & $4.3 \mathrm{a}$ & $0.34 \mathrm{a}$ & $8.75 \mathrm{c}$ & $17.06 \mathrm{c}$ \\
\hline $\mathrm{T}_{1}(7$ days interval) & $5.4 \mathrm{a}$ & $3.9 \mathrm{~b}$ & $0.44 \mathrm{a}$ & $15.40 \mathrm{a}$ & $18.30 \mathrm{c}$ \\
\hline $\mathrm{T}_{2}(14$ days interval $)$ & $5.1 \mathrm{a}$ & $4.6 \mathrm{a}$ & $0.43 \mathrm{a}$ & $14.32 \mathrm{a}$ & $24.02 \mathrm{~b}$ \\
\hline $\mathrm{T}_{3}(21$ days interval $)$ & $4.7 \mathrm{~b}$ & $4.4 \mathrm{a}$ & $0.38 \mathrm{a}$ & $13.8 \mathrm{ab}$ & $29.64 \mathrm{a}$ \\
\hline
\end{tabular}

Values in each column indicated by similar letters are not significantly different at $\mathrm{P} \leq 0.05$

\section{Conclusion}

Findings of this research indicate that application of NPK @ 10-10-15 kg ha ${ }^{-1}$ at 7 days intervals through drip irrigation to "Sahel hybrid" tomatoes in high tunnels could be recommended to the growers of Peshawar Valley or of similar agro-climatic regions for higher tomato productivity and quality.

\section{Authors' contributions}

Conceived and designed the experiments: $\mathrm{P}$ Khan \& M Imtiaz, Performed the experiments: P Khan, M Imtiaz \& SA Ali, Analyzed the data: P Khan \& SA Ali, Contributed materials/ analysis/ tools: P Khan, M Imtiaz \& SA Ali, Wrote the paper: P Khan, M Imtiaz \& SA Ali.

\section{Acknowledgement}

We acknowledge The University of Agriculture, Peshawar, Endowment Fund for providing financial support for this project.

\section{References}

1. Afzal I, Munir F, Ayub CM, Basra SA, Hameed A \& Shah F (2013). Ethanol priming: an effective approach to enhance germination and seedling development by improving antioxidant system in tomato seeds. Acta Sci Pol, Hortorum Cultus 12: 129-137.

2. FAO (2016). Countries tomato statistics. http://www.fao.org/faostat/en/\#data/QC

3. FAO (Food and Agriculture Organization) of the United Nations
(2017). Soil Fertility Atlas of Pakistan: The Punjab Province. Ahmad W, Niino Y, Zia MH, Mahmood K, Ashraf A, Ahmad N, Salim M \& Shakir MA (Eds.), ISBN 978-969-8304-08-9. Islamabad, Pakistan, pp. 115.

4. GoP (2016). Pakistan statistical year book. 2015-16. Ministry of statistics, Pak Bur Stat Islamabad, Pakistan.

5. FAO (Food and Agriculture Organization) of the United Nations (2017b). Soil Fertility Atlas of Pakistan: The Sindh Province. Ahmad W, Niino Y, Zia MH, Mahmood K, Ashraf A, Memon KS, Shah ZH, Aslam M, Ahmad N, Salim M \& Shakir MA (Eds.), ISBN 978-9698304-09-6. Islamabad, Pakistan, pp. 105.

6. Hwalla N, Labban SE \& Bahn RA (2016). Nutrition security is an integral component of food security. Front Life Sci 9: 167-172.

7. Hemming S, Mohammadkhani V \& Ruijven JV (2013). Technology of diffuse greenhouse covering materialsinfluence on light transmission, light scattering and light spectrum. ISHS. Acta Hort 1037: 883-895.

8. Rashid R (1986). Mapping zinc fertility of soils using indicator plants and soil analysis. Ph. D. Dissertation, University of Hawaii, HI, USA.

9. Story EN, Kopec RE, Schwartz SJ \& Harris GK (2010). An update on the 
health effect of tomato lycopene. Annu Rev Food Sci Technol 1: 189-210.

10. Nasir M, Khan AS, Basra SA \& Malik AU (2016). Foliar application of moringa leaf extract, potassium and zinc influence yield and fruit quality of 'Kinnow' mandarin. Scientia Hort 210: 227-235.

11. Bouyoucos GJ (1962). Hydrometer method improved for making particle size analysis of soils. Agron J 54: 464-465.

12. Jackson ML (1962). Soil Chemical Analysis. Prentice Hall Inc., Englewood Cliffs, NJ, 151-185.

13. Watanabe FS \& Olsen SR (1965). Test of an ascorbic acid method for determining phosphorus in water and $\mathrm{NaHCO}_{3}$ extracts from soil. Soil Sci Soc Am Proc 29: 677-678.

14. Nelson DW \& Sommers LE (1982). Total carbon, organic carbon and organic matter. P. 574-577. In: Methods of soil analysis. Part 2: $2^{\text {nd }}$ edition AL. Page, RH. Miller \& DR. Keeney (eds.) American Society of Agronomy, Madison, WI. USA.

15. AOAC (2000) Official Methods of Analysis. $17^{\text {th }}$ Edition, the Association of Official Analytical Chemists, Gaithersburg, MD, USA.

16. Lowry OH, Rosebrough NJ, Farr AL \&. Randall RJ (1951). Protein measurement with theFolin phenol reagent. J Biol Chem 193: 265-275.

17. AOAC, 2005. Vitamin C in foods. Official Method 967.26. In: Official Methods of Analysis, $18^{\text {th }}$ ed. Association of Official Analytical Chemists, Gaithersburg, MD, USA, pp. 45.1.16.

18. Ruck JA (1961). Chemical method for fruit and vegetable products. Res. Sta. Summerland; Res. Branch, Canada. Dept. of Agric No. 1154.

19. Balemi T (2008). Response of tomato cultivars differing in growth habit to nitrogen and phosphorus fertilizers and spacing on vertisol in Ethiopia. Acta Agric Slovenica 91: 103-119.

20. Fandi M, Muhtaseb J \& Hussein M (2010). Effect of N, P, K concentrations on yield and fruit quality of tomato (Solanum lycopersicum L.) in tuff culture. J Cent Eur Agric 11: 179-184.

21. Zekri M \& Obereza TA (2003). Micronutrient deficiencies in citrus: Iron, zinc and manganese. Institute of Food and agricultural Services, University of Florida, USA.

22. Khokhar KM, Hussain SI, Mahmood T, Hidayatullah \& Laghari MH (2002). Winter Production of Tomato under Plastic Tunnel. Asian J Plant Sci 6: 659660.

23. Hussain SI, Khokar KM, Laghari MH \& Mahmud MM (2001). Yield potential some exotic and one local tomato cultivars grown for summer production. Pakistan J Biol Sci 4: 1215-1216.

24. Chaudhry MF, Khokhar KM, Hussain SI, Mahmood T \& Iqbal SM (1999). Comparative performance of some local and exotic tomato cultivars during spring and autumn seasons. Pak J Arid Agric 2: 7-10.

25. Fandi M, Al-Muhtaseb JA \& Hussein MA (2008). Yield and Fruit Quality of Tomato as Affected by the Substrate in an Open Soilless Culture. Jordan J Agric Sci 4: 65-72.

26. Chaurasia SNS, Singh KP \& Rsi M (2005). Effect of foliar application of water soluble fertilizers on growth, yield, and quality of tomato (Lycopersicon esculentum L.). Sri Lankan J Agric Sci 42: 66-70.

27. Shibli RA, Ereifej KI, Ajlouni MA \& Hussain (1995). Evaluation of thirteen open pollinated cultivars and three hybrids of tomato. II. Physical properties and chemical composition of fruits. Pak J Agric Sci 32: 225-234. 
28. Fontes PCR \& de Araujo C (2006). Use of a chlorophyll meter and plant visual aspect for nitrogen management in tomato fertigation. J Appl Hort 8: 8-11.

29. Dorais M, Papadopoulos AP \& Gosselin A (2001). Greenhouse tomato fruit quality. Hort Rev Amer Soc Hort Sci 26: 239-319.

30. Javaria S, Khan MQ, Rahman HU \& Baksh I (2012 b). Response of tomato yield and post-harvest life to potash levels. Sarhad J Agric 28(2): 227-235.

31. Sepat NK, Kumar A, Yadav J \& Srivastava RB (2012). Effect of integrated nutrient management on growth, yield and quality of tomato in Trans Himalayan. Annals Plant Soil Res 14: 120-123.

32. Etminan M, Takkouche B \& Caamano F (2004). The role of tomato products and lycopene in the prevention of prostate cancer: a meta-analysis of observational studies. Cancer Epidemiol. Biomarkers Prev 13: 340- 345.

33. Cakmak I (2002). Plant nutrition research: Priorities to meet human needs for food in sustainable ways. Plant \& Soil 247: 3-24.
34. Lester GE, Jifon JL \& Makus DJ (2006). Supplemental foliar potassium applications with or without as urfactant can enhance netted muskmelon quality. Hort Sci 41(3): 741-744.

35. Ayeni LS (2010). Effect of cocoa pod ash, NPK fertilizer and their combinations on soil chemical properties and yield of tomato (Lycopersicon esculentum) on two soil types. New York Sci J 3: 1-10.

36. Faraz AS, Ghulam N, Muhammad NK, Shafiullah, Shah R, Saeed UR \& Sayed MAS (2021). Performance of Tomato Cultivars Transplanted on Various Dates under the Agro-Climatic Conditions of District Buner. Pure Appl Biol 10(2): 416-429.

37. Fuentes E, Carle R, Astudillo L, Guzmán L, Gutiérrez M, Carrasco G \& Palomo I (2013). Antioxidant and antiplatelet activities in extracts from green and fully ripe tomato fruits (Solanum lycopersicum) and pomace from industrial tomato processing. Evid. Based Complement. Alternat 867578. 